\title{
Expert System Eating Disorder To Youth With The Hybrid Methode
}

\author{
Firna Yenila, M.Kom \\ Universitas Putra Indonesia "YPTK" Padang \\ Jl. Raya Lubuk Begalung Padang \\ firnayenila@upiyptk.ac.id
}

\author{
Yogi Wiyandra, M.Kom \\ Universitas Putra Indonesia "YPTK" Padang \\ Jl. Raya Lubuk Begalung Padang \\ yogiwiyandra@upiyptk.ac.id
}

\begin{abstract}
- the research aims to provide information for the wider community about bulimia nervosa that often afflicts the community especially teenagers. Bulimia nervosa is one type of psychiatric disorder that is habitual that has ingrained from the community itself. No people understand the symptoms or indications of eating disorder in adolescents, and not infrequently among sufferers not doing direct treatment or looking for a direct solution to this disorder. To communicate with doctors also have constraints with time and confusion about what is to be conveyed. Expert system is a solution, this system is able to provide information to researchers about eating disorders in adolescents and provide solutions like a doctor or nutrition expert. It was built using by hybrid method which combines certainty factors and forward chaining.
\end{abstract}

Keywords - Expert System; Eating Disorder; Hybrid;

\section{INTRODUCTION}

Eating disorders often occur among teenagers day by day. Many factors make it become. And usually it is triggered by one's life style. It is can be categorized as a mental illness that will have a negative impact on one's psychic (Franko et al. 2018).

The experts say that eating disorders are psychiatric conditions with serious psychological and medical consequences(Haslinda, Ernalia, and Wahyuni n.d.). Eating disorders, such as anorexia nervosa (AN) and bulimia nervosa (BN), are chronic diseases that are defined as eating disorders or behavior in controlling weight (Kurniawan, Briawan, and Caraka 2015).

Generally, the people who have perfectionist traits that are always self-oriented have a greater risk of experiencing it. They are who has it condition have high expectations for themselves, including the state of their body shape (Kusuma, Bintanah, and Handarsari 2016). This if left unchecked will have a negative impact on health, and will no doubt also cause sudden death. To find this out, it is provided convenience to the public in the form of general knowledge about eating disorders by providing updated information in accordance with expert knowledge (Noviyanti and Marfuah 2017).

That knowledge can be given directly by experts or nutritionists in direct consultation but also by using a system in the form of an expert system
(Fanny 2017). Therefore an expert system was built using a hybrid method that combines two methods in finding facts, namely the hybrid method (Yucesan, Gul, and Celik 2018). In this hybrid method a search with forward chaining and certainty factor is used. Forward chaining is a method of tracking data at the beginning to provide clear information, the information is strengthened by using certainty factor methods that provide certainty of the value of information in the form of a percentage (Wiyandra and Yenila 2018).

\section{Literature Review}

\subsection{Expert System}

The expert system is an activity of adaptation of someone's expertise that is transferred into the system (Yenila and Wiyandra 2019). This system provides direct information to users about information about it that often occur among adolescents (Akil et al. 2017)

\subsection{Inference engine}

The expert system was built using a hybrid method, which combines the forward chaining method with certainty factors. These two methods have different steps and different ways of delivering output (Hasibuan et al. 2017): 
a. Forward chaining

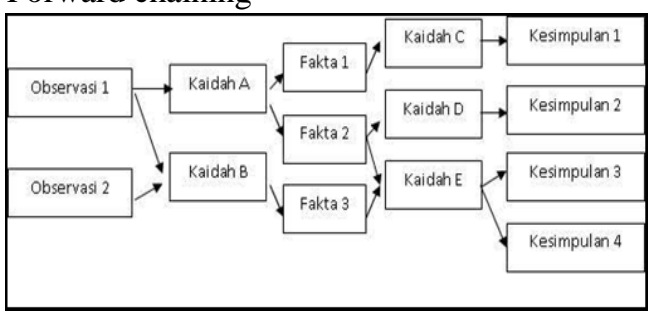

Figure 1 The rule of Forward Chaining

Forward Chaining is a search of technique that starts with known facts, then matches facts from the IF part of the IF - THEN rule (Limantara, Winarto, and Mudjanarko 2017). If there is a fact that matches the IF section, then the rule is executed (Krisnanik 2018).

When the rules are executed, new facts (THEN section) are added to the database (Hasibuan et al. 2017).

The steps in creating an expert system using the forward chaining method are (Nurajizah et al. 2018):

a. Defining the problem starts with the selection of the problem domain and the acquisition of knowledge

b. Dendefenesian input data to start inference because it is required by the forward chaining system.

c. Define the data control structure to help control the activation of a rule.

d. Writing the initial code in the domain of knowledge

e. Testing the system in order to know the extent to which the system is running

f. Interface design based on knowledge

g. System development

h. System evaluation

\section{b. Certainty Factor}

The Certainty Factor method shows a measure of certainty about a fact or rule(Putri and Saputra 2018). Certainty Factor is a clinical parameter value given by MYCIN to show the amount of trust. The advantage of the Certainty Factor method is that it can measure something that is certain or uncertain in making decisions on this expert system (Sihotang 2014).

The basic formula of Certainty Factor:

$C F(h, e)=M B(h, e)-M D(h, e)(1)$

Information:

a. $\mathrm{CF}(\mathrm{h}, \mathrm{e})=$ Certainty Factor (factor certainty) in hypothesis $h$ is influenced by evidence (symptoms) e. b. MB (h, e ) = Measure of Belief (confidence level), is a measure of the confidence of the hypothesis $\mathrm{h}$ influenced by evidence (symptoms) e.

c. $M D(h, e)=$ Measure of Disbelief (level of uncertainty), is a measure of mistrust of the hypothesis

$\mathrm{d}$. $\mathrm{h}$ is influenced by symptoms e.

e. $\mathrm{h}=$ The resulting hypothesis or conclusion (between 0 and 1 ).

f. e = Evidence or event or fact (symptom)

The next calculation is a combination of two or more rules with different evidence but in the same hypothesis(Ramadhan n.d.):

Rule $1 C F(h, e 1)=C F 1=C(e 1) x C F($ Rule 1$)(2)$

Rule $2 C F(h, e 2)=C F 2=C(e 2) x C F($ Rule2) (3)

$C F$ combinasi $[C F 1, C F 2]=C F 1+C F 2(1-C F 1)(4)$

\section{Metodology Research}

The form of the research framework used in designing this system is as follows:

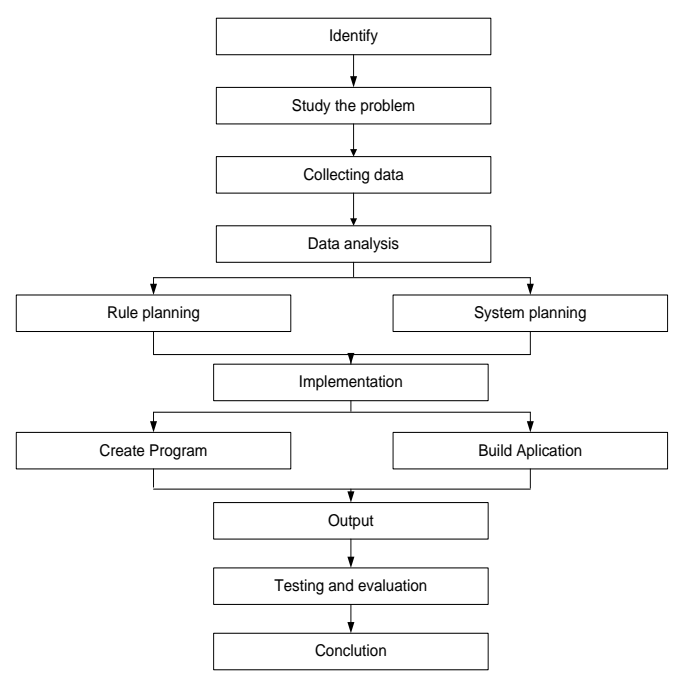

Figure 2 Metodology Research

Based on Figure 2 it can be explained that the stages of the implementation of this study began from identifying problems and setting goals, which aim to maintain consistency of this research so that this research is more directed, and the objectives of the research are expected to be achieved. Then the library review is continued, namely studying literature, journals, books related to research (problems that have been identified).

The next stage in this research is the collection of data and information, this stage is conducted to find out how to get data and information that will 
later support this research, in data collection, there are several methods used, namely field research, library research (library research ), and laboratory research (laboratory research). After data collection, the next step is a system analysis designed based on the identification of the problem and the data obtained.

The next stage is system design which consists of application design and program design. After this stage is completed, then it enters the implementation phase, which is making applications and making programs to get results, which are then tested and evaluated. After that a conclusion is drawn from the trial and evaluation of the results that have been carried out.

\section{Analysis and Results}

Symptoms of eating disorders that are felt by patients can be seen from the following table 1:

Table 1 Symptoms of Eating Disorders

\begin{tabular}{|l|l|}
\hline \multicolumn{1}{|c|}{ Code } & Symptoms of Disease \\
\hline G001 & Excessive weight loss \\
\hline G002 & Look thin and not ideal weight \\
\hline G004 & $\begin{array}{l}\text { Loss of sexual desire } \\
\text { such as palpitations }\end{array}$ \\
\hline G005 & Low blood pressure \\
\hline G006 & Kidney failure \\
\hline G007 & $\begin{array}{l}\text { Dry skin on hands and feet due } \\
\text { to lack of blood flow }\end{array}$ \\
\hline G008 & Dehydration \\
\hline G009 & $\begin{array}{l}\text { Vomiting or abusing laxatives } \\
\text { or diuretics in an effort to lose } \\
\text { weight }\end{array}$ \\
\hline G010 & $\begin{array}{l}\text { Use the bathroom often after } \\
\text { meals }\end{array}$ \\
\hline G011 & Excessive exercise \\
\hline G012 & $\begin{array}{l}\text { Preoccupation or think } \\
\text { constantly about weight }\end{array}$ \\
\hline G013 & Tooth problem \\
\hline G014 & Sore throat \\
\hline G015 & Depression or mood swings \\
\hline G016 & Feeling out of control \\
\hline G017 & $\begin{array}{l}\text { Swollen glands in the neck and } \\
\text { face }\end{array}$ \\
\hline G018 & $\begin{array}{l}\text { Heartburn, indigestion, and } \\
\text { bloating }\end{array}$ \\
\hline G019 & Irregular menstruation \\
\hline G020 & Weakness, fatigue, and red eyes \\
\hline G021 & Can't stop myself when eating \\
\hline
\end{tabular}

\begin{tabular}{|l|l|}
\hline G022 & $\begin{array}{l}\text { Quickly consume food in large } \\
\text { portions }\end{array}$ \\
\hline G023 & $\begin{array}{l}\text { Keep eating even though you } \\
\text { already feel full }\end{array}$ \\
\hline G024 & Hide when eating \\
\hline G025 & $\begin{array}{l}\text { Eat normally in front of people } \\
\text { but when you eat alone, eat } \\
\text { greedily }\end{array}$ \\
\hline G026 & $\begin{array}{l}\text { Always eat almost all day and } \\
\text { do not have time to eat }\end{array}$ \\
\hline G027 & $\begin{array}{l}\text { Feel stressed and depressed } \\
\text { then think you can only calm } \\
\text { down if you eat }\end{array}$ \\
\hline G028 & $\begin{array}{l}\text { The growth of hair or fine hairs } \\
\text { all over the body (lanugo) }\end{array}$ \\
\hline G029 & Dry skin \\
\hline G030 & Muscle becomes weak \\
\hline G031 & $\begin{array}{l}\text { Often feel cold due to low body } \\
\text { temperature }\end{array}$ \\
\hline G032 & $\begin{array}{l}\text { Menstruation becomes } \\
\text { irregular, does not even } \\
\text { experience menstruation }\end{array}$ \\
\hline G033 & $\begin{array}{l}\text { Hypotension or low blood } \\
\text { pressure }\end{array}$ \\
\hline G034 & Anemia or lack of blood \\
\hline G035 & Bone Loss \\
\hline
\end{tabular}

Table 2 Types of Eating Disorders

\begin{tabular}{|l|l|}
\hline \multicolumn{1}{|c|}{ Code } & \multicolumn{1}{c|}{ Types of Disorders } \\
\hline J001 & Anorexia Nervosa \\
\hline J002 & Bulimia Nervosa \\
\hline J003 & Binge eating disorder \\
\hline J004 & Ortoreksia nervosa \\
\hline
\end{tabular}

Table 3 The Point of Certainty Factor

\begin{tabular}{|c|l|c|}
\hline No & Information & Value By User \\
\hline 1 & Not & 0 \\
\hline 2 & Do not know & 0.2 \\
\hline 3 & A little sure & 0.4 \\
\hline 4 & Pretty sure & 0.6 \\
\hline 5 & Sure & 0.8 \\
\hline 6 & Very sure & 1 \\
\hline
\end{tabular}

Table 4 Certainty Factor Value for Each Premise

\begin{tabular}{|c|l|c|}
\hline Code & \multicolumn{1}{|c|}{ Symptoms of Disease } & Point \\
\hline G001 & Excessive weight loss & 0.7 \\
\hline G002 & $\begin{array}{l}\text { Look thin and not ideal } \\
\text { weight }\end{array}$ & 0.6 \\
\hline G003 & Loss of sexual desire & 0.5 \\
\hline
\end{tabular}




\begin{tabular}{|c|c|c|}
\hline G004 & $\begin{array}{l}\text { Disorders of the heart } \\
\text { organ, such as } \\
\text { palpitations }\end{array}$ & 0.9 \\
\hline G005 & Low blood pressure & 0.7 \\
\hline G006 & Kidney failure & 0.8 \\
\hline G007 & $\begin{array}{l}\text { Dry skin on hands and } \\
\text { feet due to lack of } \\
\text { blood flow }\end{array}$ & 0.4 \\
\hline G008 & Dehydration & 0.5 \\
\hline G009 & $\begin{array}{l}\text { Vomiting or abusing } \\
\text { laxatives or diuretics in } \\
\text { an effort to lose weight }\end{array}$ & 0.8 \\
\hline G010 & $\begin{array}{l}\text { Use the bathroom often } \\
\text { after meals }\end{array}$ & 0.5 \\
\hline G011 & Excessive exercise & 0.4 \\
\hline G012 & $\begin{array}{l}\text { Preoccupation or think } \\
\text { constantly about } \\
\text { weight }\end{array}$ & 0.7 \\
\hline G013 & Tooth problem & 0.4 \\
\hline G014 & Sore throat & 0.8 \\
\hline G015 & $\begin{array}{l}\text { Depression or mood } \\
\text { swings }\end{array}$ & 0.7 \\
\hline G016 & Feeling out of control & 0.4 \\
\hline G017 & $\begin{array}{l}\text { Swollen glands in the } \\
\text { neck and face }\end{array}$ & 0.5 \\
\hline G018 & $\begin{array}{l}\text { Heartburn, indigestion, } \\
\text { and bloating }\end{array}$ & 0.6 \\
\hline G019 & Irregular menstruation & 0.4 \\
\hline G020 & $\begin{array}{l}\text { Weakness, fatigue, and } \\
\text { red eyes }\end{array}$ & 0.8 \\
\hline G021 & $\begin{array}{l}\text { Can't stop myself when } \\
\text { eating }\end{array}$ & 0.7 \\
\hline G022 & $\begin{array}{l}\text { Quickly consume food } \\
\text { in large portions }\end{array}$ & 0.9 \\
\hline G023 & $\begin{array}{l}\text { Keep eating even } \\
\text { though you already feel } \\
\text { full }\end{array}$ & 0.4 \\
\hline G024 & Hide when eating & 0.1 \\
\hline G025 & $\begin{array}{l}\text { Eat normally in front of } \\
\text { people but when you } \\
\text { eat alone, eat greedily }\end{array}$ & 0.8 \\
\hline G026 & $\begin{array}{l}\text { Always eat almost all } \\
\text { day and do not have } \\
\text { time to eat }\end{array}$ & 0.7 \\
\hline G027 & $\begin{array}{l}\text { Feel stressed and } \\
\text { depressed then think } \\
\text { you can only calm } \\
\text { down if you eat }\end{array}$ & 0.8 \\
\hline G028 & $\begin{array}{l}\text { The growth of hair or } \\
\text { fine hairs all over the } \\
\text { body (lanugo) }\end{array}$ & 0.7 \\
\hline G029 & Dry skin & 0.2 \\
\hline G030 & Muscle becomes weak & 0.5 \\
\hline
\end{tabular}

\begin{tabular}{|l|l|c|}
\hline G031 & $\begin{array}{l}\text { Often feel cold due to } \\
\text { low body temperature }\end{array}$ & 0.8 \\
\hline G032 & $\begin{array}{l}\text { Menstruation becomes } \\
\text { irregular, does not even } \\
\text { experience } \\
\text { menstruation }\end{array}$ & 0.6 \\
\hline G033 & $\begin{array}{l}\text { Hypotension or low } \\
\text { blood pressure }\end{array}$ & 0.7 \\
\hline G034 & $\begin{array}{l}\text { Anemia or lack of } \\
\text { blood }\end{array}$ & 0.7 \\
\hline G035 & Bone Loss & 0.8 \\
\hline
\end{tabular}

The new rules are then calculated with certainty value using information provided by the expert using the Certainty Factor method by the user using the following equation:

$$
\begin{aligned}
\mathrm{CF}(\mathrm{H}, \mathrm{E}) & =\mathrm{CF}(\mathrm{E}) * \mathrm{CF} \text { (rule) } \\
& =\mathrm{CF}(\text { user }) * \mathrm{CF} \text { (expert) }
\end{aligned}
$$

The final step is to combine the certainty factor values of each rule that is combined

$\mathrm{CF} 1$ up to $\mathrm{CF} 4$ with the equation

$$
\begin{aligned}
& \begin{aligned}
\text { CFCOMBINE(CF1,CF2) }= & \text { CF } 1+\text { CF } 2 *(1-\text { CF1 }) \\
\text { CFCOMBINE }(\mathrm{CF} 1, \mathrm{CF} 2)= & 0,7+0,6 *(1-0,7) \\
= & 0,7+0,18 \\
= & 0,78 \text { CFold }
\end{aligned} \\
& \begin{aligned}
\text { CFCOMBINE (CFold,CF3) } & 0,78+0,5 *(1-0,78) \\
= & 0,78+0,11 \\
= & 0,89 \text { CFold }
\end{aligned} \\
& \begin{aligned}
\text { CFCOMBINE (CFold,CF4) } & =0,89+0,9 *(1-0,89) \\
& =0,89+0,09 \\
& =0,98 \text { Cfold }
\end{aligned}
\end{aligned}
$$

From the above conditions, the percentage of confidence $=$ CFCOMBINE $* 100 \%$ is obtained, that is $0.98 \times 100 \%=98 \%$ which states that based on certainty weights, it is stated that we are very confident.

a. System Implementation

The system was built by making it easy for users to provide information or ease in consultation. The first step taken by the system is to consult to provide complaint information from the user first and then provide a statement form to the user in the form of a confidence level or weight value of the conditions experienced.

After finishing using the initial display further on other system activities that are conducting consultations between the user and the system. Information provided in the form of events experienced by the user. 


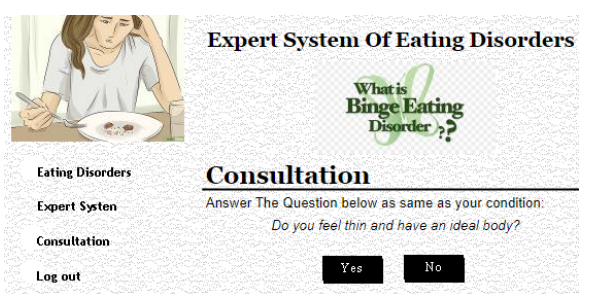

Figure 4 Consultation Display

Accoding by consultation activities can be provided information to patients about eating disorders faced by patients. After the first question is answered yes by the user then go to the next form which is to give the certainty value / weight given to the question. How sure is the user experiencing the conditions in the questions.

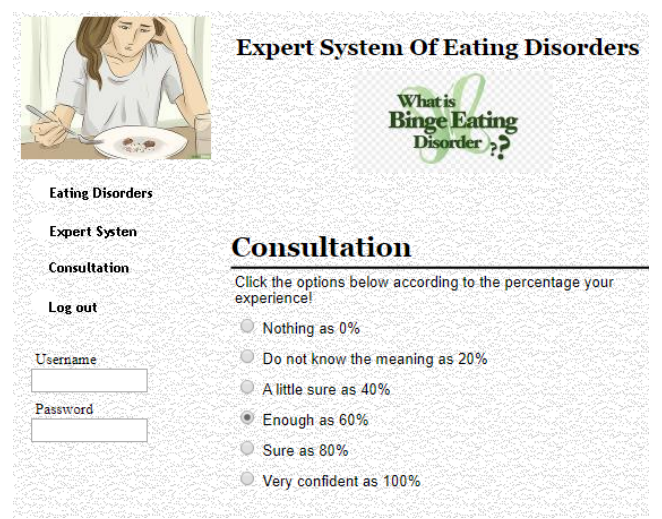

Figure 5 Certainty Factor

From the certainty of weight in accordance with the questions raised by the system conclusions / results from the system can be drawn as follows:

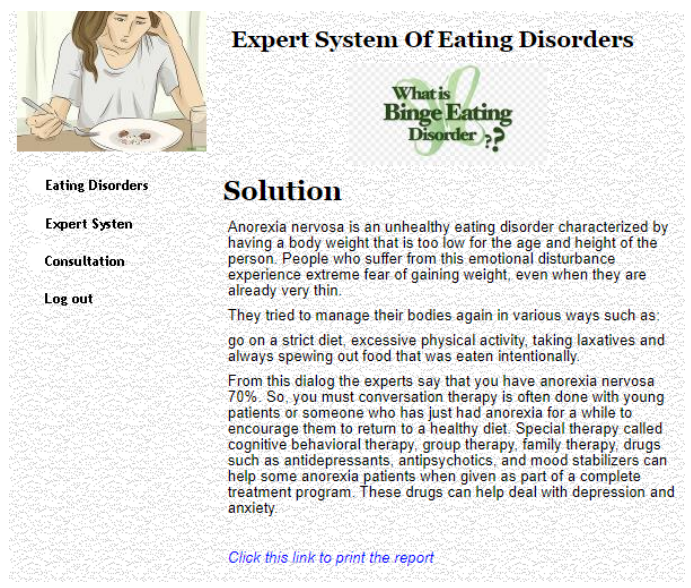

Figure 6 Conclusions
The results of the conclusions of the study can be used in a hard copy and can be used by users when needed.

\section{Conclution}

Based on the analysis and discussion carried out, it can be concluded several things as follows:

1. There are several factors that can determine appendicitis. The influencing factors are obtained from several choices given by the system, so that an expert system plan will be produced to determine which patients have inflammation of the intestine

2. The system designed can determine the possibility of inflammation of the intestine of the patient based on the user's chosen data entered.

3. Reasoning is done by using the backward chaining method with the aim of giving a percentage of the possibility of the patient experiencing intestinal inflammation.

4. The output of this system is in the form of information to help patients with intestinal inflammation or treatment for people with inflammation of the intestine in the initial stages which are seen by using a system in the form of hardcopy.

\section{Reference}

Akil, Ibnu, Program Studi, Manajemen

Administrasi, and Jakarta Timur. 2017.

"ANALISA EFEKTIFITAS METODE

FORWARD CHAINING DAN." 13(1): 3542.

Fanny, Rahmi Ras. 2017. "RENALIS

MENGGUNAKAN METODE CERTAINTY

FACTOR DENGAN PENULUSURAN

FORWARD CHAINING." Sistem Pakar diagnosa ASIDOSIS TUBULUS RENALIS 1(1): 13-16.

Franko, Debra L et al. 2018. "Predictors of LongTerm Recovery in Anorexia Nervosa and Bulimia Nervosa : Data from a 22-Year Longitudinal Study." Journal of Psychiatric Research 96(July 2017): 183-88. http://dx.doi.org/10.1016/j.jpsychires.2017.10. 008.

Hasibuan, Nelly Astuti, Hery Sunandar, Senanti Alas, and Mahasiswa Teknik Informatika. 
2017. "GAJAH MENGGUNAKAN METODE CERTAINTY." Sistem pakar mendiagnosa penyakit kaki gajah (1): 29-39.

Haslinda, Lilly, Yanti Ernalia, and Sri Wahyuni. "Citra Tubuh, Perilaku Diet, Dan Kualitas Hidup Remaja Akhir Mahasiswa Fakultas Kedokteran Universitas Riau.” : 95-98.

Krisnanik, Erly. 2018. "DESAIN MODEL SISTEM PAKAR PERTUMBUHAN JANIN BERDASARKAN TRI SEMESTER MENGGUNAKAN FORWARD." : 13-18.

Kurniawan, Mohamad Yulianto, Dodik Briawan, and Rezzy Eko Caraka. 2015. "Jurnal Gizi Klinik Indonesia Persepsi Tubuh Dan Gangguan Makan Pada Remaja.” 11(03): 10514.

Kusuma, Hapsari Sulistya, Sufiati Bintanah, and Erma Handarsari. 2016. "TINGKAT KECUKUPAN ENERGI DAN PROTEIN PADA STATUS BALITA SEMARANG Karakteristik Balita Status Pemilih Makan Balita Tabel 4 . 1 Status Pemilih Makan Balita." : 557-64.

Limantara, Arthur Daniel, Sigit Winarto, and Sri Wiwoho Mudjanarko. 2017. "SISTEM PAKAR PEMILIHAN MODEL PERBAIKAN PERKERASAN LENTURBERDASARKAN INDEKS KONDISI PERKERASAN ( PCI )." (November): 1-2.

Noviyanti, Retno Dewi, and Dewi Marfuah. 2017. "Hubungan Pengetahuan Gizi , Aktivitas Fisik , Dan Pola Makan Terhadap Status Gizi Remaja Di Kelurahan Purwosari Laweyan Surakarta." : 421-26.

Nurajizah, Siti, Maulana Saputra, Manajemen Informatika, and Sistem Informasi. 2018. "SISTEM PAKAR BERBASIS ANDROID UNTUK DIAGNOSA PENYAKIT.” 14(1): 7-14.
Putri, Sukmawati Anggraeni, and Elin Panca Saputra. 2018. "Perancangan Aplikasi Sistem Pakar Diagnosa Awal Kanker Reproduksi Wanita Dengan Metode Certainty Factor." 2(3): 63-68.

Ramadhan, Puji Sari. "SISTEM PAKAR PENDIAGNOSAAN DERMATITIS IMUN MENGGUNAKAN TEOREMA BAYES." (73): 43-48.

Sihotang, Hengki Tamando. 2014. "SISTEM PAKAR MENDIAGNOSA PENYAKIT KOLESTEROL PADA REMAJA DENGAN METODE CERTAINTY FACTOR ( CF ) BERBASIS WEB.” 15(1): 16-23.

Wiyandra, Yogi, and Firna Yenila. 2018. "BEKAS PADA BASOKA MOTOR DENGAN MENGGUNAKAN." 5(1): 23-34.

Yenila, Firna, and Yogi Wiyandra. 2019. "Sistem Pakar Deteksi Apendisicitis." 5(3): 81-91.

Yucesan, Melih, Muhammet Gul, and Erkan Celik. 2018. "Performance Comparison between ARIMAX , ANN and ARIMAX-ANN Hybridization in Sales Forecasting for Furniture Industry i Hibridizacije ARIMAXANN u Predvi đ Anju Prodaje Za Industriju Namještaja.” 69(4): 357-70. 